\title{
Strategi Program Pencegahan Penyalahgunaan Narkoba Pada Badan Narkotika Nasional Provinsi Kalimantan Tengah
}

\section{The Strategy Of Drug Abuse Prevention Program At The National Narcotic Body Of Central Kalimantan Province}

\section{Anggelina Hariyanti"}

Universitas Muhammadiyah Palangkaraya, Palangka Raya, Central Kalimantan, Indonesia

email:

anggelinahariyanti366@gmail.com

\section{Kata Kunci: \\ Strategi \\ Program \\ Pencegahan \\ Penyalahgunaan \\ Narkotika}

\section{Keywords:}

Strategy

Program

Prevention

Abuse

Narcotics

Accepted

June 2019

Published

Oktober 2019

\begin{abstract}
Abstrak
Penelitian ini bertujuan untuk mengetahui Strategi Program Pencegahan Penyalahgunaan Narkoba pada Badan Narkotika Nasional Provinsi (BNNP) Kalimantan Tengah. Penelitian ini menggunakan pendekatan kualitatif. Tehnik Pengumpulan data terdiri dari Data Primer dan Data Sekunder. Teknik pengumpulan data dalam penelitian ini adalah Observasi, Wawancara, Studi Dokumentasi. Teknik analisa data dengan cara reduksi data, penyajian data dan penarikan kesimpulan.

Hasil penelitian menunjukkan Strategi Pencegahan Penyalahgunaan Narkoba pada Badan Narkotika Nasional Provinsi (BNNP) Kalimantan Tengah adalah (I) Demand Side, yakni penyelenggaraan fungsi diseminasi informasi dan advokasi P4GN kepada masyarakat. Sasarannya adalah meningkatnya daya tangkap masyarakat terhadap bahaya penyalahgunaan dan peredaran gelap narkoba di kalangan coba pakai (2) Supply Side, strategi yang ditempuh melalui pelaksanaan pencegahan dan pemberantasan penyalahgunaan dan peredaran gelap narkoba melalui media; penguatan lembaga terapi dan rehabilitasi korban penyalahguna dan/atau pecandu narkoba secara terpadu; serta penguatan kegiatan intelijen narkoba. (3) Hambatan BNNP Kalimantan Tengah dalam Pelaksanaan Strategi Pencegahan Penyalahgunaan Narkoba antara lain terbatasnya jumlah sumber daya manusia BNNP Kalimantan Tengah, kurangnya kesadaran masyarakat dan minimnya kebijakan tentang penanganan narkotika.
\end{abstract}

\section{PENDAHULUAN}

Permasalahan penyalahgunaan narkotika saat ini sudah sangat mengkhawatirkan baik secara nasional maupun internasional. Dikarenakan korban penyalahgunaan narkotika tidak hanya terbatas pada kelompok masyarakat yang mampu saja akan tetapi telah merambah ke kalangan masyarakat kurang mampu baik di kota maupun di desa. Tidak terlepas juga di Kalimantan Tengah khususnya di kota Palangka Raya juga terdapat banyak pengguna narkotika baik dari kalangan orang dewasa hingga ke kalangan anak-anak. 
Terlihat dari data pengguna narkotika di Kalimantan Tengah pada tahun 2017 berjumlah sebanyak 217 orang dan mengalami kenaikan pada tahun 2018 sebanyak 137 orang yang dilakukan rehabilitasi. Penyalahgunaan narkoba di Kalimantan Tengah pada tahun 2017 tercatat sebanyak 38.98I orang dan pada tahun 2018 jumlah pengguna narkoba di Kalimantan Tengah meningkat hingga 42.000 orang lebih. Angka ini tentunya bukan jumlah angka yang sedikit. Melihat dari besarnya jumlah pengguna narkotika yang ada di Kalimantan Tengah, menuntut peran aktif dari pemerintah terutama Badan Narkotika Nasional Provinsi (BNNP) Kalimantan Tengah untuk melakukan upaya-upaya pencegahan penyalahgunaan narkotika.

Selain itu, pelaksanaan pencegahan penyalahgunaan narkoba juga merupakan tugas utama yang dilakukan oleh Badan Narkotika Nasional Provinsi (BNNP) Kalimantan Tengah yang tertuang dalam Peraturan Kepala Badan Narkotika Nasional Nomor 23 Tahun 2017 tentang Perubahan Kelima Atas Peraturan Kepala Badan Narkotika Nasional Nomor 3 Tahun 2015 tentang Organisasi dan Tata Kerja Badan Narkotika Nasional Provinsi dan Badan Narkotika Kabupaten /Kota. Aparat pemerintah memegang peranan penting dalam pelaksanaan dan penyelenggaraan pemerintah, walaupun partisipasi masyarakat serta faktor lainnya tidak dapat diabaikan.

Dalam melaksanakan program pencegahan penyalahgunaan narkoba, pemerintah daerah khususnya BNNP telah melakukan inovasi dengan merangkul seluruh elemen masyrakat melalui perwakilan seperti Ketua RT, Tokoh Agama, Tokoh Pemuda, Tokoh Adat dan sebagainya untuk menjadi bagian dari proses P4GN tersebut. Dimana diharapkan dalam melibatkan para tokoh masyarakat ini dapat lebih intens menyampaikan informasi terkait larangan penyalahgunaan narkoba serta bahaya yang akan ditimbulkan apabila melakukan penyalahgunaan narkoba.

Hal ini dilakukan oleh BNNP karena mengingat terbatasnya juga kemampuan BNNP dalam melakukan sosialisasi kepada masyarakat, dimana dalam pelaksanaaan kegiatan sosialisasi kepada masyarakat itu cukup terbatas dalam satu tahun, sedangkan pengaruh dari para pengedar khususnya selalu bisa terjadi setiap saat. Oleh sebab itu, maka pihak BNNP melakukan sosialisasi kepada tokoh masyarakat terutama guru-guru dan tenaga pengajar yang intensitas pertemuannya sering berinteraksi langsung dengan masyarakat, diberikan arahan dan diharapkan mereka dapat menyampaikan setiap saat kepada anak didiknya terutama untuk menjauhi penggunaan narkoba.

Inovasi tersebut dilakukan oleh BNN Provinsi Kalimantan Tengah, karena mereka menyadari bahwa masih memiliki berbagai kendala diantaranya adalah terkait pembiayaan yang memiliki keterbatasan untuk dapat melakukan sosialisasi kepada seluruh lapisan masyarakat, selain itu juga masih sedikitnya ketersediaan SDM bidang penyuluh yang dimiliki.

Dengan melihat betapa pentingnya peran BNN Provinsi Kalimantan Tengah, serta adanya banyak keterbatasan yang mereka miliki, sehingga penelitian ini dirasa menarik untuk dilakukan penelitian lebih mendalam mengenai strategi yang dilakukan oleh BNN Provinsi Kalimantan Tengah dalam Pencegahan Penyalahgunaan Narkoba yang ada di Kalimantan Tengah khususnya pada ibu kota provinsi yakni Kota Palangka Raya.

\section{TINJAUAN PUSTAKA}

Strategi pada hakikatnya adalah perencanaan (planning) dan manajemen (management) untuk mencapai suatu tujuan. Tetapi untuk mencapai tujuan tersebut, strategi tidak berfungsi sebagai peta jalan yang hanya menunjukan arah saja, melainkan harus mampu menunjukan bagaimana taktik operasionalnya (Effendy, 2007:32).

Sumber lainnya mengatakan bahwa starategi adalah pendekatan secara keseluruhan yang berkaitan dengan pelaksanaan gagasan, perencanaan dan eksekusi sebuah aktivitas dalam kurun waktu tertentu. Menurut 
Rangkuti, strategi adalah alat untuk mencapai tujuan. Tujuan utamanya adalah agar organisasi dapat melihat secara objektif kondisikondisi internal dan eksternal, sehingga organisasi dapat mengantisipasi perubahan lingkungan eksternal. (Rangkuti, 2009:3). Sedangkan menurut Michael E. Porter (dalam Rangkuti), esense dari startegi adalah memilih untuk menyuguhkan hal yang berbeda dengan apa yang disuguhkan oleh pesaing. Menurutnya, permasalahan yang muncul terjadi karena kesalahan dalam membedakan evektifitas operasional dan strategi.

\section{METODOLOGI}

Pendekatan Penelitian ini menggunakan pendekatan kualitatif yang mempunyai latar alami sebagai sumber penelitian dalam pengumpulan data, disamping itu penelitian kualitatif bersifat deskriptif dan makna temuan merupakan hal yang paling esensial dalam rancangan kualitatif. Tipe penelitian yang digunakan dalam penelitian ini adalah bersifat deskriptif. Mely G. Tan dalam Ulber Silalahi (2009:28) mengatakan: Penelitian yang bersifat deskriptif bertujuan menggambarkan secara tepat sifat-sifat suatu individu, keadaan, gejala, atau kelompok tertentu, atau untuk menentukan frekuensi atau penyebaran suatu gejala dan gejala lain dalam masyarakat.

\section{HASIL DAN PEMBAHASAN}

Dalam rangka mencapai target program P4GN maka BNNP Kalteng berkewajiban menyusun Rencana Kerja (Renja) Tahun 2019 sebagai acuan dalam pelaksanaan penyusunan program dan kegiatan pada tahun berjalan. Renja mempunyai fungsi penting dalam sistem perencanaan karena Renja menterjemahkan perencanaan strategis jangka menengah (Renstra) ke dalam rencana, program dan penganggaran tahunan. Renja menjembatani sinkronisasi, harmonisasi Renstra ke dalam langkah-langkah yang lebih kongkrit dan terukur. Dengan demikian Renja merupakan pedoman bagi penyusunan RKAKL (Rencana Kerja \& Anggaran Kementrian Negeri/Lembaga).

Pelaksanaan Pencegahan Penyalahgunaan Narkotika dilakukan berdasarkan dasar hukum yang berlaku, yang kemudian dibuat dalam sebuah rencana strategis serta rencana kerja yang akan dilaksanakan oleh BNNP Kalimantan Tengah untuk dapat mencapai visi BNNP yakni melakukan Pencegahan dan Pemberantasan Penyalahgunaan dan Peredaran Gelap Narkotika, Psikotropika, Prekursor dan Bahan Adiktif Lainnya di Indonesia untuk mencapai Indonesia bebas Narkotika.

Dalam melakukan pencegahan penyalahgunaan narkoba tentunya tidak dapat dilepaskan dari keikutsertaan atau keterlibatan masyarakat dalam pelaksanaannya. Oleh sebab itu, maka Bidang Pemberdayaan Masyarakat, BNNP Kalimantan Tengah berupaya untuk memicu kesadaran masyarakat akan pentingnya partisipasi seluruh kompunen yang ada di masyarakat untuk melakukan gerakan mencegah dan menekan laju prevalensi penyalahgunaan dari peredaran gelap narkoa di wilayah Kalimantan Tengah dengan melasanakan program P4GN. Berikut ini merupakan beberapa rangkaian kegiatan yang dilakukan dalam rangka P4GN yang dilakukan oleh BNNP Kalimantan.

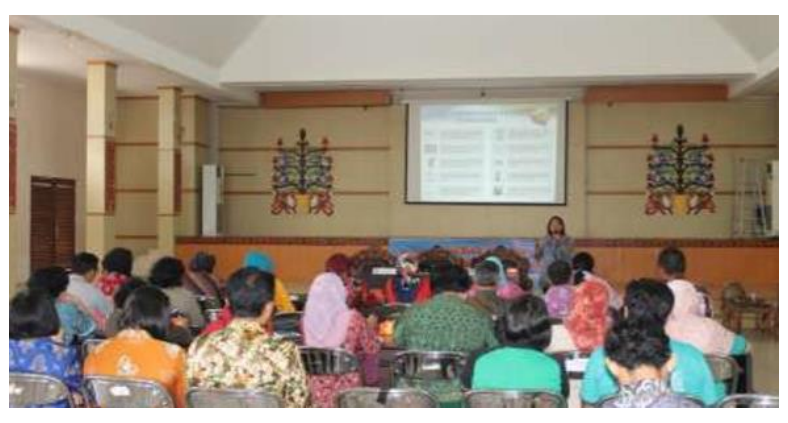

Gambar I. Sosialisasi Program Rehabilitasi Dan Pascarehabilitasi Kepada Para Kepala Sekolah Tingkat (SD) Dan (SMP)

Selain itu untuk melakukan pencegahan penyalahgunaan narkoba, BNNP Kalimantan Tengah juga melakukan berbagai kegaitan yang salah satunyanya adalah melakukan bimbingan teknis kepada BNN Kabupaten/Kota dan instansi pemerintahan. 


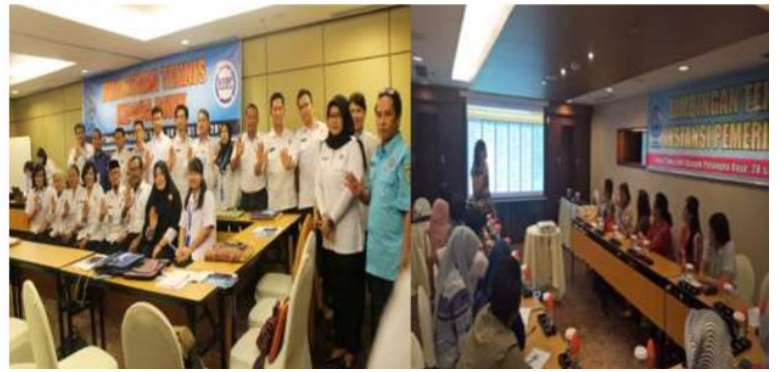

Gambar 2

Bimbingan Teknis

Selama tahun 2018, Bidang Pencegahan dan Pemberdayaan Masyarakat (P2M) BNNP Kalimantan Tengah telah melakukan kegiatan pencegahan dan pemerdayaan anti narkoba dengan kegiatan Desiminasi yakni melakukan kegiatan dengan tujuan menyebarluaskan informasi tentang bahaya narkoba kepada semua masyarakat disemua lapisan baik melalui tatap muka dengan masyarakat (penyuluhan), spanduk, baliho, sticker, pamflet leaflet, media cetak, TV dan radio, online ataupun media sosial dan media-media lainnya yang dapat digunakan secara efektif, kreatif dan tepat sasaran.

Bidang Pencegahan dan Pemberdayaan Masyarakat seksi Pencegahan Diseminasi Informasi memiliki sasaran yaitu Persentase masyarakat yang mendapat informasi P4GN sebesar $6 \%$.

Tabel I. Presentase Infromasi P4GN

\begin{tabular}{|c|c|c|c|c|c|}
\hline No & Sasaran/output & BNNP & $\begin{array}{l}\text { BNNK } \\
\text { P.Raya }\end{array}$ & $\begin{array}{l}\text { BNNK } \\
\text { Kobar }\end{array}$ & Total \\
\hline 1 & $\begin{array}{l}\text { Media Konvensional / tatap } \\
\text { muka }\end{array}$ & 400 & 200 & 11050 & 11.650 \\
\hline 2 & Media Surat Kabar & 46.041 & & & 46.041 \\
\hline 3 & Media Televisi & 2.525 & & & 2.525 \\
\hline 4 & Media Radio & 12.800 & 2500 & 20.000 & 35.300 \\
\hline 5 & Media Online & $\begin{array}{r}115.41 \\
3\end{array}$ & 939 & & 116.352 \\
\hline 6 & Bahan Kontak Diseminasi & & & & \\
\hline 7 & Pamflet, leaflet, sticker, dll & & & 12.236 & 12.236 \\
\hline 8 & Insert Konten P4GN & 2.272 & & & 2.272 \\
\hline 9 & Media cetak luar ruang & & & 1.750 & 1.750 \\
\hline 10 & Kampanye STOP NARKOBA & 500 & 553 & 1.000 & 2.053 \\
\hline & & & & & $\begin{array}{r}230.179 \\
\text { orang }\end{array}$ \\
\hline
\end{tabular}

Berdasarkan data dari Badan Pusat Statistik Palangkaraya, jumlah penduduk Provinsi Kalimantan Tengah pada tahun 2018 adalah sebanyak 2.605.274 Jiwa. Target Diseminasi Informasi P4GN BNNP Kalimantan Tengah adalah $6 \%$ dari total jumlah penduduk yang dalam angka adalah sejumlah 156.316
Jiwa. Berdasarkan data dari tabel diatas, kegiatan Diseminasi Informasi P4GN BNNP Kalimantan Tengah telah berhasil melakukan penyebaran informasi terhadap 230.179 orang penduduk Kalimantan Tengah.

BNNP Kalimantan Tengah juga melakukan Pemerdayaan Masyarakat (Dayamas) dengan menyelenggarakan pembinaan kawasan atau wilayah rawan narkoba. Kawasan atau wilayah rawan yang di intervensi program pemberdayaan alternatif BNNP Kalimantan Tengah menyasar di daerah Jl. Kalimantan, Daerah Puntun dan Daerah Dermaga Rambang Palangkaraya karena berdasarkan hasil pemetaan kawasan, daerah tersebut merupakan wilayah yang cukup marak dalam peredaran narkoba. Pembinaan kawasan rawan narkoba oleh BNNP Kalimantan Tengah dilaksanakan dalam bentuk pelatihan budidaya dan pengolahan jamur, budidaya dan pengolahan ikan keramba dan pengolahan hasil budidaya ikan. Pemberdayaan di wilayah ini belum dapat dikatakan berhasil, karena kurangnya supervisi dan keterbatasan SDM di BNNP Kalteng.

Berbagai peraturan perundangan telah diterbitkan untuk mendukung pelaksanaan tugas penanganan penyalahgunaan narkoba antara lain Undang-Undang Nomor 35 Tahun 2009 tentang Narkotika.

Dalam Undang-Undang tersebut BNN diberikan tugas dan kewenangan untuk melaksanakan pencegahan dan pemberantasan penyalahgunaan dan peredaran gelap narkotika dan prekursor narkotika serta menjadi leading sector dalam penangan permasalahan narkotika.

Untuk mencapai tujuan yang dibuat oleh BNNP Kalimantan Tengah yaitu dengan cara membuat berbagai macam program. Programprogram tersebut ada yang berdasarkan dengan Daftar Isian Pelaksanaan Anggaran (DIPA) dan ada yang berdasarkan Non DIPA. Jadi Program DIPA tersebut berdasarkan anggaran yang disalurkan dari pusat, sedangkan program Non DIPA itu permintaan dari instansi seperti sekolah-sekolah yang ada di Kalimantan Tengah terutama sekolah di Kota Palangka Raya. sasaran program/kegiatan yang dijalani 
seperti masyarakat, tokoh agama, tokoh pemuda, tokoh masyarakat, pelajar, guru dan jajaran instansi pemerintah kota/provinsi dalam bentuk penyuluhan tentang bahaya penyalahgunaan narkoba. Selanjutnya untuk bentuk-bentuk programnya adalah advokasi dan asistensi.

Advokasi yaitu kita memberikan pengajaran kepada Aparatur Pemerintah jadi mengadvokasi orang yang sudah berpendidikan, termasuk komunitas yang mempunyai rekan jadi itu yang perlu di advokasi yang bentuknya memberikan penyuluhan tentang bahaya narkoba. Sedangkan program Non DIPA yang dibuat oleh kita sendiri di tahun 2019 ini yaitu Goes To School yang dilaksanakan sesuai dengan permintaan sekolah.

Dalam rangka mencapai sasaran yang ingin dicapai BNPP Kalimantan Tengah dalam rangka pencegahan penyalahgunaan narkoba, strategi yang dilakukan oleh BNPP Kalimantan Tengah antara lain :

a. Demand Side, yakni penyelenggaraan fungsi diseminasi informasi dan advokasi P4GN kepada masyarakat. Sasarannya adalah meningkatnya daya tangkap masyarakat terhadap bahaya penyalahgunaan dan peredaran gelap narkoba di kalangan coba pakai. Akses informasi P4GN yang tepat serta kualitas informasi P4GN yang baik menjadi kata kunci penting bagi keberhasilan upaya diseminasi informasi P4GN dalam meningkatkan daya tangkal masyarakat. Selain itu peningkatan daya tangkal masyarakat jugadiharapkan tercapai melalui pelaksanaan advokasi secara persuasif dan bertahap dalam mendorong lahirnya aturakebijakan P4GN yang sinergis dan integral di berbagai lingkungan masyarakat. Untuk mendukung pencapaian sasaran tersebut dibutuhkan kerangka regulasi bidang pencegahan dalam bentuk Peraturan Pemerintah Pelaksanaan Undang-undang tentang Kewajiban Seluruh Elemen Masyarakat (termasuk media massa) Dalam Upaya Pencegahan dan Pemberantasan. b. Supply Side, strategi yang ditempuh melalui pelaksanaan pencegahan dan pemberantasan penyalahgunaan dan peredaran gelap narkoba di daerah. Strategi ini dilakukan melalui media; penguatan lembaga terapi dan rehabilitasi korban penyalahguna dan/atau pecandu narkoba secara terpadu; serta penguatan kegiatan intelijen narkoba.

Dalam rangka melakukan penanganan penyalahgunaan narkoba harus seimbang antara demand reduction dan supplay reduction, yaitu mengembangkan berbagai upaya dalam penanganan permasalahan narkoba secara holistik, integral, dan berkelanjutan. Serta mengedepankan profesionalisme, dedikasi, dan tanggung jawab dalam penanganan permasalahan narkoba.

Adapun strategi yang lakukan oleh BNNP Kalimantan Tengah untuk melaksanakan demand reduction dan supplay reduction adalah melalui :

a. ekstensifikasi dan intensifikasi informasi P4GN kepada seluruh lapisan masyarakat.

b. menumbuhkembangkan kepedulian dan kemandirian masyarakat dalam rangka pelaksanaan P4GN.

c. mengembangkan akses layanan rehabilitasi penyalahguna, korban penyalahgunaan, dan pecandu narkoba yang terintegrasi dan berkelanjutan.

d. melakukan pengungkapan jaringan sindikat narkoba dan menyita seluruh aset terkait kejahatan narkoba.

e. menjalin kemitraan yang harmonis dan sinergis dengan berbagai komponen baik dalam maupun luar negeri dalam rangka optimalisasi pelaksanaan P4GN.

f. mengembangkan budaya dan nilai-nilai organisasi dalam rangka terciptanya aparatur yang mampu memberikan pelayanan secara prima, memiliki integritas tinggi, dan profesional dalam bertugas.

g. mengoptimalisasi dukungan teknologi informasi yang modern dan tepat guna dalam pelaksanaan P4GN. 
Dalam pelaksanaan strategi untuk dapat melakukan pencegahanpenyalahgunaan narkoba oleh Badan Narkotika Nasiona Provinsi Kalimantan Tengah masih menemui berbagai hambatan seperti aparat BNNP Kalimantan Tegah yang masih kurang secara kuantitas, kesadaran hukum masyarakat, serta sarana dan fasilitas pendukung. Adapun hal ini akan dijabarkan sebagai berikut :

a. Kurangnya Petugas BNN Provinsi Kalimantan Tengah

Keterbatasan jumlah sumber daya manusia yang di miliki oleh BNNP Kalimantan Tengah sangat mempengauhi terhadap pelaksanaan program khususnya dalam rangka pencegahan penyalahgunaan narkotika. Luas wilayah yang harus di pantau dengan SDM yang ada tidak mempuni.

b. Kurangnya Kesadaran Masyarakat

Kurangnya keterlibatan masyarakat secara sukarela, mandiri, dan menjunjung tinggi nilai-nilai kemanusiaan (humanis) dalampelaksanaan program P4GN yang disebabkan karena adanya anggapan bahwa masalah narkoba adalah urusan pemerintah saja serta bukan keluarga mereka dan penyalah guna narkoba harus dipenjara sehingga mereka menjadi tidak produktif dan tidak berperan dalam kehidupan bermasyarakat dan berbangsa.

c. Minimnya Kebijakan Anti Narkoba

Merupakan sasaran dari program Advokasi yang memiliki maksud untuk memberikan intervensi guna pengembangan kebijakan anti narkoba oleh para pemangku kepentingan dalam hal ini adalah program Pembangunan Berwawasan Anti Narkoba (BANGWAWAN) sehingga pemerintah daerah, SKPD, lingkungan Pendidikan, swasta dan masyarakat Kalimantan Tengah memiliki inisiasi dalam pengembangan kebijakan pendukung P4GN untuk menolak dan melawan narkoba. BNNP Kalimantan memiliki slogan "KALTENG BERSINAR MENUJU KALTENG BERKAH" sebagai slogan kampanye melawan narkoba merupakan salah sa tu contoh bahwa BNNP Kalteng relatif cukup berhasil dalam menggerakkan pemerintah Daerah di Wilayah Kalimantan Tengah.

\section{KESIMPULAN}

Berdasarkan hasil penelitian yang telah dipaparkan sebelumnya, Strategi Pencegahan Penyalahgunaan Narkoba pada Badan Narkotika Nasional Provinsi (BNNP) Kalimantan Tengah sebagai berikut.

I. Demand Side, yakni penyelenggaraan fungsi diseminasi informasi dan advokasi P4GN kepada masyarakat. Sasarannya adalah meningkatnya daya tangkap masyarakat terhadap bahaya penyalahgunaan dan peredaran gelap narkoba di kalangan coba pakai

2. Supply Side, strategi yang ditempuh melalui pelaksanaan pencegahan dan pemberantasan penyalahgunaan dan peredaran gelap narkoba melalui media; penguatan lembaga terapi dan rehabilitasi korban penyalahguna dan/atau pecandu narkoba secara terpadu; serta penguatan kegiatan intelijen narkoba.

3. Hambatan BNNP Kalimantan Tengah dalam Pelaksanaan Strategi Pencegahan Penyalahgunaan Narkoba antara lain terbatasnya jumlah sumber daya manusia BNNP Kalimantan Tengah, kurangnya kesadaran masyarakat dan minimnya kebijakan tentang penanganan narkotika.

\section{REFERENSI}

Atik dan Ratminto, 2005. Manajemen Pelayanan, disertai dengan pengembangan model konseptual, penerapan citizen charter dan standar pelayanan minimal. Yogyakarta : Pustaka Pelajar.

David. 2010. Manajemen Strategis. Yogyakarta BPFE.

Harbani Pasalong. 2012. Teori Administrasi Publik. Alfabeta. Yogyakarta. 
Kuncoro, Mudrajad. 2005. Strategi (Bagaimana Meraih Keunggulan Kompetitif). Jakarta: Penerbit Erlangga.

Rangkuti Fredy, 2015. Analisis SWOT : teknik membedah kasus bisnis.

Rangkuti, 2019. Manajemen Strategis. Alfabeta : Yogyakarta.

Sukanto Reksohadiprodjo. 2003. Manajemen Strategis. Yogyakarta BPFE.

T. Hani Handoko, 20II. Pengantar Manajemen. Udayana University.

Thompson dan Sqtrickland. 2003. Manajemen Strategi. Ulber Silalahi. 2009. Metode Penelitian Sosial. Bandung. PT. Refika Aditama.

\section{Dokumen dan Perundang-undangan}

Laporan Akuntabilitas Kinerja Instansi Pemerintah Tahun 2018 BNN Provinsi Kalimantan Tengah. Peraturan Kepala Badan Narkotika Nasional Nomor 23 Tahun 2017 tentang Perubahan Kelima Atas Peraturan Kepala Badan Narkotika Nasional Nomor 3 Tahun 2015 tentang Organisasi dan Tata Kerja Badan Narkotika Nasional Provinsi dan Badan Narkotika Kabupaten/Kota

Peraturan Presiden Republik Indonesia Nomor 23 Tahun 2010 tentang Badan Narkotika Nasional.

Rencana Kerja (Renja) Tahunan BNNP Kalimantan Tengah Tahun 2018.

Rencana Kerja (Renja) Tahunan BNNP Kalimantan Tengah Tahun 2019.

Rencana Strategis (Rentra) BNNP Kalimantan Tengah 2018.

Rencana Strategis (Rentra) BNNP Kalimantan Tengah 2019 